\title{
PORFIRIO DIAZ
}

Porfirio Diaz, the former president of Mexico, and one of the most remarkable figures in the modern history of Latin America, died in Paris on July 2nd last, an exile from the country in which for thirty-one years he was not only the ruler, but, in the words of Louis XIV, "l'etat; c'est moi." From 1876 until 1911, Mexico was Diaz, and Diaz was Mexico. Within those dates, our sister republic saw its most prosperous epoch and experienced a material progress which lifted it from the condition of an undeveloped and backward nation into the rank of a leading nation of the world, with the prospect before it of a further industrial and commercial development not unlike that which had already come to the United States. The five years which have elapsed since Diaz was driven into exile, have been some of the saddest years in the history of Mexico, and as yet she sees little sign of better days. No contrast more vivid and more tragic can be found between the pages of her history. It is worth while to look a little closely into the causes underlying this extraordinary transformation; and in doing so we must briefly recount the life of this remarkable man.

Porfirio Diaz was born in 1830 at Oaxaca, a region which has since produced more than its quota of radical leaders. His father was an innkeeper, and one-eighth of his blood was Indian. Orphaned when three years old, he was educated under the patronage of the bishop of Oaxaca, who destined him for the church. At the age of seventeen, he enlisted for the war with the United States, but saw little fighting. He went back to Oaxaca, and was a professor in the Law Institute there when the radical uprising against Santa Anna broke out. Diaz joined the rebels, was proscribed, and thereafter continued his career as a soldier. There followed the crusade against the church, then all powerful in Mexico, under the leadership of Benito Juarez. Diaz was one of bis generals, and proved himself a soldier of great daring and brilliant strategy. In the internal war of 1855-61, he commanded the army which saved Mexico City and the Congress from the clerical attack. It was at this juncture that Mexico faced the international crisis arising out of the repudiation by the Juarez government of securities held by citizens of Spain, France and England, which countries landed joint armaments at Vera Cruz in October, 1861. When the schemes of Napoleon III for extending his imperialistic plans became evident, Spain and England withdrew. The 
French remained at Vera Cruz, and in 1862 advanced on Puebla, where they were met and defeated by General Diaz. But a year later another French army was dispatched to Mexico, which besieged Diaz at Puebla, and forced his surrender after desperate fighting. The capture of Mexico City and the installation of Maximilian as Emperor of Mexico soon followed. Then ensued a protracted guerilla warfare, in which Diaz went through extraordinary adventures, was several times captured and escaped, and finally recaptured Puebla, repulsed the Imperialist army advancing from Mexico City, and on June 21, captured the capital, two days after Maximilian had surrendered at Queretara. It was the intervention of the United States, at the close of the Civil War, which made possible the expulsion of the French invaders; but the military glory of the achievement belonged to Diaz, and made him the idol of the Mexican people.

Diaz might then have taken the presidency of the Republic; but loyalty to his old chief Juarez dictated his retirement to the estate near Oaxaca given him by the people of that state. More disorders followed; in 1872, Juarez dying, Lerdo de Tejada became president under the Constitution. His four years' term was marked by a series of conspiracies and insurrections, with the people discontented and impoverished. Finally in 1876, Diaz, going to Texas, there organized a revolution in the radical northern provinces. His resources were inadequate; he was defeated in battle after battle, and after a series of hairbreadth escapes, he succeeded in reaching the soutb, where he again raised an army, and at the great battle of Tecoac defeated the Lerdistas, and in November, 1876, became the President of Mexico.

Diaz devoted his first term to the restoration of order and to efforts to reconcile the political factions by which the nation was torn. He retired at the end of four years to make way for Gonzales, and during the latter's term of office, he travelled extensively in the United States. In 1884 , it was generally recognized that he was the only man who could save Mexico from herself; he was elected President again, and remained in the office without serious opposition, until 1911.

There followed what is generally regarded as the golden era in the history of Mexico. A transformation began almost immediately. The President encouraged the building of railroads and telegraphs, the development of mines and plantations, water works, sanitation. $\mathrm{He}$ beautified and extended the capital city, built opera houses, and above all else, established a system of free public education and put the re- 
public on a sound financial basis. Foreign capital quickly gained confidence and flowed into the country from Europe and the United States, greatly to its benefit and development. Diaz gathered about him administrators and financiers of recognized ability, and the machinery of government was efficient. The thirty years of his presidency, during which he was sometimes re-elected by methods recognized as extraconstitutional, marked an era of industrial and economic growth never previously known in Mexico, and hardly surpassed in the United States during the same time.

But throughout the later years of his regime the embers of discontent and revolution were smouldering in Mexico, and the government only rested secure upon the army. The administration of the criminal law was a farce, and the courts were notoriously venal and incompetent. Administrative scandals arose; many of the president's official adherents were undoubtedly corrupt and more than one was false to him; but it must be said for him personally that he accumulated no fortune and died a comparatively poor man.

As Diaz grew old, his iron grip upon the situation gradually loosened; his splendid army dwindled to a skeleton; men whom he trusted intrigued against him. General Bernardo Reyes, the Governor of Nuevo Leon, organized an insurrection, and was promptly put in jail; but after him came Francisco I. Madero, a political dreamer not unlike the type of the French revolutionist. He started a revolution in San Antonio, and conducted a presidential campaign from within the walls of a prison. But the insurrection grew from guerilla outbreaks into a widely extended revolution, with which a honeycombed government was unable to cope. Discouraged, disgusted and worn out, Diaz resigned on May 5, 1911, and at once left the country, never to return.

What has happened to our unfortunate neighbor since is still current history; what will happen to it in the future, no man can foretell. But truth compels the statement that the happiest and most progressive epoch in Mexico's history was the thirty years of Diaz's supremacy. Following the establishment of Mexican independence in 1810, down to 1876 , the country was in the hands of seventy-nine executive heads, including an emperor, many presidents, many dictators, and never with a firm government. As time passes, the conviction will grow that Diaz was its wisest as well as its strongest ruler. But it must be admitted that the Diaz regime was fatal to itself. It was not a government founded upon the solid rock of representative institutions, and no democracy can 
live which is governed in any other way. Porfirio Diaz will live in history as one of the great generals of his country; he will live as a great executive, who realized the splendid possibilities of Mexico, who knew its weakness and sought to educate his people. But it is true that his policy aimed at the exploitation of the Mexican nation rather than its development on the broad lines that must underlie democratic institutions.

We cannot close this inadequate sketch of a useful and remarkable career without recording the fact that President Diaz was always a firm friend of the United States. During the long period of his supremacy, no diplomatic misunderstandings arose which were not peaceably adjusted in the spirit of true friendship. He shares with President Roosevelt the honor of submitting the first international controversy to the Hague tribunal for determination, by promptly accepting the offer of the United States to refer to the decision of that tribunal the controversy over what is known as "The Pious Fund of the Californias." In so doing the two American republics not only vivified The Permanent Court of Arbitration at The Hague, but set an example to all the world, which has since been followed in many instances for the settlement of international disputes. In his honor an American president went outside American territory for the first time when President Taft visited him at Ciudad Juarez in October, 1909.

\section{THE WILLIAM P. FRYE CASE}

In our last issue (page 497) a summary was given of the negotiations between the United States and Germany over the sinking of the American vessel William P. Frye by the German auxiliary cruiser Prinz Eitel Friedrich. It appeared at that time that Germany had admitted liability under the treaties between the United States and Prussia of 1799 and 1828 for the damages sustained by American citizens, but held that the case should be submitted to the German prize court at Hamburg. It also appeared that the United States did not see any reason for submitting the case to the German prize court. Germany having admitted her liability under the treaties, the status of the claimants and the amount of the indemnity were the only questions remaining to be settled, which the United States suggested could be more properly dealt with through diplomatic channels.

From the correspondence exchanged since that time, however, it is 